\title{
Immunogenicity of porcine circovirus type 2 nucleic acid vaccine containing $C p G$ motif for mice
}

\author{
Jun $\mathrm{Li}^{1 \dagger}$, Jiang $\mathrm{Yu}^{1 \dagger}$, Shaojian $\mathrm{Xu}^{1 \dagger}$, Jianli Shi', Shengnan $\mathrm{Xu}{ }^{1}$, Xiaoyan $\mathrm{Wu}^{1}$, Fang $\mathrm{Fu}{ }^{2}$, Zhe Peng ${ }^{1}$, Lingling Zhang ${ }^{1}$, \\ Shuxuan Zheng ${ }^{1}$, Xiaoyuan Yuan ${ }^{1}$, Xiaoyan Cong ${ }^{1}$, Wenbo Sun ${ }^{1}$, Kaihui Cheng ${ }^{1}$, Yijun Du', Jiaqiang Wu' \\ and Jinbao Wang ${ }^{1 *}$
}

\begin{abstract}
Background: This study aimed at reseaching the immune effect of porcine circovirus type 2 (PCV2) DNA vaccine containing CPG motif on mice.

Methods: A total of 40 6-week-old female BALB/c mice were randomly divided into four groups which were immunized by 18CpG-pVAX1-ORF2, pVAX1-ORF2, pVAX1 and PBS, respectively, and immunized again 2 weeks later. All mice were challenged with $0.2 \mathrm{~mL}$ PCV2 cells virulent strain SD $\left(10^{6.0} \mathrm{TCID}_{50} / \mathrm{mL}\right)$ after 4 weeks. Average daily gain, blood antibody levels, microscopic changes and viremia were detected to estimate the effect of DNA vaccine.

Results and Discussion: The results showed that compared to those of the control mice, groups immunized with pVAX1-ORF2 and 18CpG-pVAX1-ORF2 could induce PCV2-specific antibodies. The PCV2-specific antibodies level of 18 CpG-pVAX1-ORF2 groups was higher significantly than other groups and decreased slowly along with time. There was no distinct pathological damage and viremia occurring in mice that inoculated with CpG motif DNA vaccines. The results demonstrated that the DNA vaccine containing $18 \mathrm{CpG}$ could build up resistibility immunity and reduce immune organ damage on mice.
\end{abstract}

Keywords: Porcine circovirus type 2, Nucleic acid vaccine, Immunogenicity, CpG motifs, Mice

\section{Background}

Porcine circovirus (PCV) is a small, nonenveloped, icosahedral virus containing a circular single-stranded DNA genome, which is assigned to the Circoviridae family. PCV comprises with two genotypes, which are non-pathogenic PCV1 and pathogenic PCV2 [1]. The former exist widely in PK-15 cells, and the latter is closely related with postweaning multisystemic wasting syndrome (PMWS) [2], which mainly infect weaned pigs and fattening pigs. Nowadays, porcine circovirus type 2 (PCV2) has become one of the most important pathogens affecting the swine industry worldwide [3]. PCV2 contains at least two major open reading frames (ORFs). ORF1 encodes the

\footnotetext{
*Correspondence: wangjb@saas.ac.cn

${ }^{\dagger}$ Equal contributors

${ }^{1}$ Division of Swine Diseases, Shandong Provincial Key Laboratory of Animal Disease Control \& Breeding, Institute of Animal Science and Veterinary Medicine Shandong Academy of Agricultural Sciences, Jinan 250100, China Full list of author information is available at the end of the article
}

replication proteins (Rep and Rep') which involved in virus replication, and ORF2 encodes the capsid proteins (Cap) were found to be immunogenic which made them suitable for vaccine development [4].

Currently, PCV2 vaccination is still an important method to combat porcine circovirus diseases (PCVD). At present, chimeric viruses, subunit vaccines, recombinant vaccines, genetic engineering vaccines and other kind of vaccines were researched at home and abroad. However, the most successful vaccine candidates were those based on the induction of an active immune response against the capsid protein of PCV2 [5-7].

Some domestic and international reports have showed that $\mathrm{CpG}$ motifs have the effect of immunostimulation as an immune adjuvant $[8,9]$. CpG motifs can activate the immune system by enhancing the antigen presentation capacity of APC. The current research on CpG as immune adjuvant was mainly focused on the mouse and human 
disease. Based on the earlier research in the authors 'laboratory (Cheng $\mathrm{KH}$, "Study on Series of DNA Vaccines Against Porcine Circovirus Type 2[D],"[master's thesis QingDao Agricultural University, 2009]), we first reported the CpG motifs as an adjuvant insert to the PCV2 DNA vaccine that could boost immunity in pigs [10].

Our research and other research had showed that mouse could be infected by PCV2 and used as a PCV2 infected experimental model $[11,12]$. In this study,we evaluate immune effect of PCV2 DNA vaccine with CpG motif on mice using the best CpG motif from our earlier research [10], which can provide a great prospect for preventing and controlling PCVD, in order to give candidate vaccine evaluation model.

\section{Methods}

\section{Viruses and vaccine}

The titer of PCV2 strain SD on PK-15 cells (DQ478947) was $10^{6.0} \mathrm{TCID}_{50} / \mathrm{ml}$. PCV2 strain SD,DNA vaccine plasmid 18CpG-pVAX1-ORF2,plasmids pVAX1-ORF2 and pVAX1 were constructed by Cheng Kaihui and saved by Shandong Key Laboratory of Animal Disease Control \& Breeding. PCV2 strain SD was also preserved in Chinese bacterium Preservation Center (CGMCC NO.5774).

\section{Animal vaccination}

Six-week old female BALB/c mice (Shandong province Experimental Animal Centre, China) were divided randomly into four groups (10 mice/group), which were immunized intramuscular injection in legs by $18 \mathrm{CpG}-$ pVAX1-ORF2, pVAX1-ORF2, pVAX1 or PBS, respectively, and immunized again after 2 weeks (Table 1). All mice were challenged intramuscularly with $0.2 \mathrm{~mL}$ PCV2 cells virulent strain SD $\left(10^{6.0} \mathrm{TCID}_{50} / \mathrm{mL}\right)$ after 4 weeks. Average daily gain was recorded everyday during the experiment. All mice experimental procedures were performed in accordance with the Regulations for the Administration of Affairs Concerning Experimental Animals approved by the State Council of People's Republic of China.

Table 1 Groups distribution and Immunization of six-week-old mice

\begin{tabular}{lll}
\hline Groups & $\begin{array}{l}\text { Immunized recombinant } \\
\text { plasmid }\end{array}$ & Dosage \\
\hline I(Control) & PBS & $0.2 \mathrm{~mL}$ \\
II & pVAX1 & $0.2 \mathrm{~mL}$ (Plasmid concentration \\
& & $500 \mu \mathrm{g} / \mathrm{mL})$ \\
III & pVAX1-ORF2 & $0.2 \mathrm{~mL}($ Plasmid concentration \\
& & $500 \mu \mathrm{g} / \mathrm{mL})$ \\
IV & 18CpG-pVAX1-ORF2 & $0.2 \mathrm{~mL}($ Plasmid concentration \\
& & $500 \mu \mathrm{g} / \mathrm{mL})$ \\
\hline
\end{tabular}

\section{Physical signs studies}

The change of body weight was recorded at the time of vaccinations, and before PCV2 cells virulent strain challenge. Average daily gain was calculated to evaluate the vaccine effection.

\section{Assay of mice blood antibody levels}

The blood samples was collected at the time of vaccinations, 2 weekly intervals during immunity period and weekly after challenge until necropsy, respectively. The serum were separated and detected blood antibody levels with PCV2-dCap-ELISA kit (Tianjin ringpu biotechnology Limited by Share Ltd) according to the manufacturer's directions. The positive cutoff was set at $\mathrm{S} / \mathrm{P} \geq$ 0.25 when $\mathrm{S} / \mathrm{P}=\left(\mathrm{OD}_{450}\right.$ of sample $-\mathrm{OD}_{450}$ mean of negative control $) /\left(\mathrm{OD}_{450}\right.$ mean of positive control $\mathrm{OD}_{450}$ mean of negative control).

\section{Pathological and histopathology studies}

The mice were euthanized at 3 weeks after challenge and samples from the lung, spleen and liver were fixed in $10 \%$ neutral-buffered formalin solution, and were sectioned and stained with hematoxylin and eosin (HE). Microscopic changes were determined by comparing the tissues of the challenged mice with those of the control-groups.

\section{Assay of PCV2 distribution by Real-time PCR}

Real-time PCR was used to detect the virus in the neck muscles, heart, liver, spleen, lung, kidney and blood. One pair of polymerase chain reaction (PCR) primers D1 $5^{\prime}$ TTACCGGCGCACTTCGGCAG $-3^{\prime}$ and D2 $5^{\prime}$ ACTCCGTTGTCCCTGAGAT - 3 ' were designed using computer software (Primer Premier 5.0) according to the published sequence of the PCV2 in GenBank (DQ478947) to establish a fluorescent quantitative PCR assay for the detection of PCV2 (404 bp). The amplification was carried out in a $25 \mu \mathrm{L}$ reaction containing $1 \mu \mathrm{M}$ of each forward and reverse primer, $12.5 \mu \mathrm{L}$ of SYBR Green I Mix (TaKaRa), $2 \mu \mathrm{L}$ DNA templates, and $\mathrm{ddH}_{2} \mathrm{O}$ up to $25 \mu \mathrm{L}$. The PCR conditions were as follows: $95{ }^{\circ} \mathrm{C}$ for $10 \mathrm{~min}$, followed by 30 cycles of amplification at $95{ }^{\circ} \mathrm{C}$ for $10 \mathrm{~s}$, and $55^{\circ} \mathrm{Cfor} 10 \mathrm{~s}$ [13]. The assays were repeated at least three times, with each experiment performed in triplicate.

\section{Statistical analysis}

All data were performed using SPSS 15.0 software (SPSS Inc., Chicago, IL, USA). Statistical analyses were analyzed by two-way analysis of variance (ANOVA) followed by Tukey's post hoctest, respectively. Differences were considered significance at $p<0.05$. 


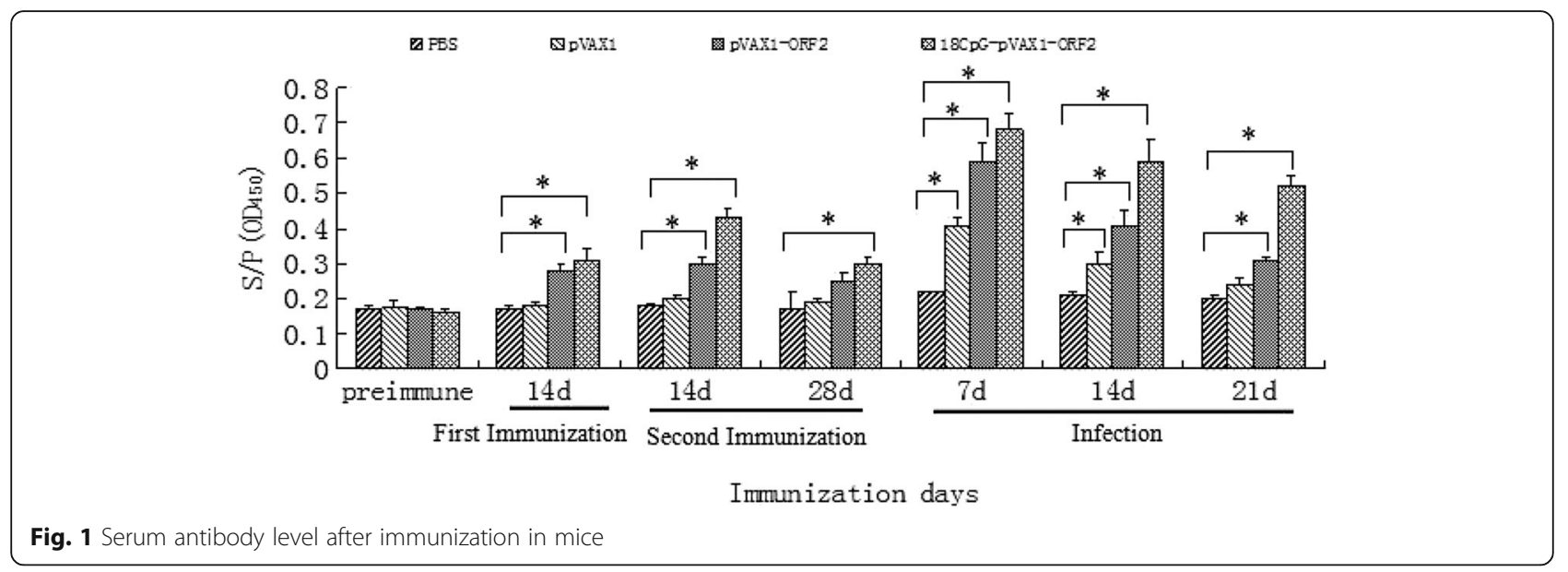

\section{Result}

Average daily gain (ADG)

Body weight was recorded at day 1 and 4 week, ADG of every mouse was calculated and statistical analyses were performed. The result showed that compared to the control mice (group I),there was no significant difference among groups $(p \geq 0.05)$, and the weight gain was not altered by vaccination in mice.

\section{Assay of blood antibody detection}

Porcine circovirus type 2 (PCV2)-antibody responses monitored by PCV2-ORF2 protein enzyme-linked immunosorbent assay. The antibody level of group III and IV was rised gradually after first immunization, and group IV showed an obvious rise after secondary immunization, while group III rised within a narrow range. However, the antibody of group IV was still up to 0.3097 at 4 week after secondary immunization, which was positive. Thus, the immune effect of DNA vaccine containing $18 \mathrm{CpG}$ was better than other groups throughout the time after vaccination. After challenge with PCV2 strain SD, the antibody level of the four groups was all rised due to the anamnestic response in the vaccinated groups, and the highest level was appeared at 1 week after challenge. The antibody level of group IV was higher significantly than other groups $(p<0.05)$, and decreased slowly along with time
(Fig. 1). The results of mice blood antibody detection $(\mathrm{S} / \mathrm{P})$ was showed in Table 2.

\section{Clinical observation and pathological changes}

All mice of group I and II becoming lean, almost emaciated and displayed splenomegaly, No obvious clinical signs and gross lesions were observed in the vaccinated group mice of group III and IV.

The alveolar walls thicked and inflammatory cells infiltrated in lung bronchia were showed in mice of group I (Fig. 2a). Interstitial pneumonia, and congestion were observed in alveolar interlobular interval and infiltration with inflammatory cells (Fig. 2b) while the hepatocyte showed slight atrophy and hemorrhage (Fig. 2j) in group II mice. A few of inflammatory cells were observed in alveoli of group III (Fig. 2c). Degenerative necrosis in kidney tubules and wider congestion in the glomeruli were observed in group I-III (Fig. 2e, f, g). Typical slight vacuoles granular degeneration was observed in hepatocyte of group I (Fig. 2i) and III (Fig. 2k), respectively. No obvious unusual changes were observed in lungs, kidney and liver of group IV (Fig. 2d, h, l). The result showed that the DNA vaccine containing $18 \mathrm{CpG}$ could provide an effective immune protection.

\section{Quantitative analysis of PCV2 expression in tissues and blood} The PCV2 contents in blood and different tissues were calculated at 1,2 and 3 weeks after injection (Table 3,

Table 2 Serum antibody level after immunization in mice (S/P)

\begin{tabular}{|c|c|c|c|c|c|c|c|}
\hline Groups & $\begin{array}{l}\text { Pre-immune } \\
\text { blood }\end{array}$ & $\begin{array}{l}\text { Blood after the first } \\
\text { immunization two } \\
\text { weeks }\end{array}$ & $\begin{array}{l}\text { Blood after the } \\
\text { second immunization } \\
\text { two weeks }\end{array}$ & $\begin{array}{l}\text { Blood after the } \\
\text { second immunization } \\
\text { four weeks }\end{array}$ & $\begin{array}{l}\text { Blood after } \\
\text { injection one } \\
\text { week }\end{array}$ & $\begin{array}{l}\text { Blood after } \\
\text { injection two } \\
\text { weeks }\end{array}$ & $\begin{array}{l}\text { Blood after } \\
\text { injection three } \\
\text { weeks }\end{array}$ \\
\hline 1 & 0.1507 & 0.1510 & 0.1601 & 0.1500 & 0.2329 & 0.2206 & 0.1993 \\
\hline$\|$ & 0.1507 & 0.1628 & 0.2052 & 0.1862 & 0.4249 & 0.3084 & 0.2426 \\
\hline III & 0.1507 & 0.2576 & 0.3003 & 0.2417 & 0.5928 & 0.4267 & 0.3223 \\
\hline IV & 0.1507 & 0.3127 & 0.4340 & 0.3097 & 0.6754 & 0.5795 & 0.5186 \\
\hline
\end{tabular}



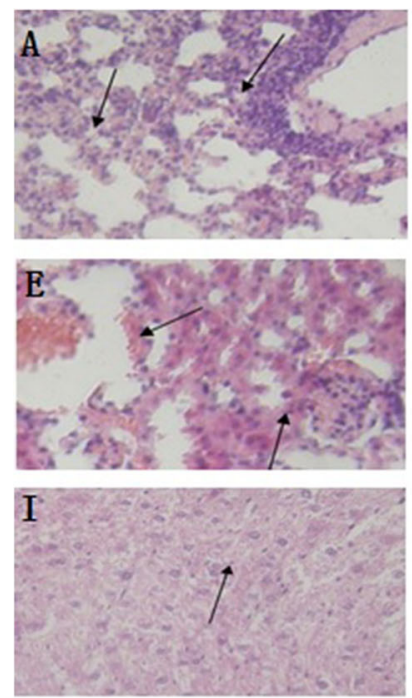
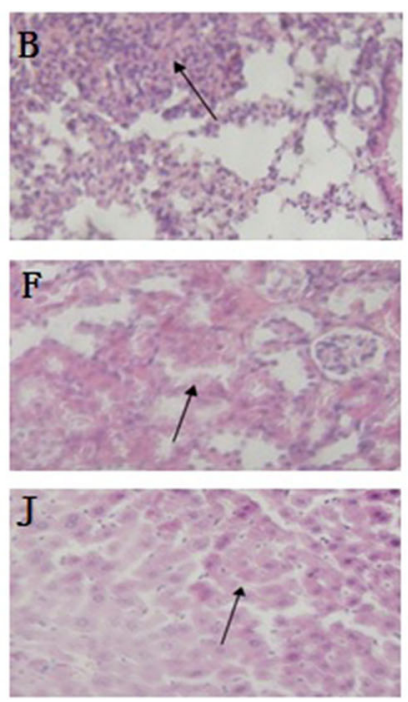
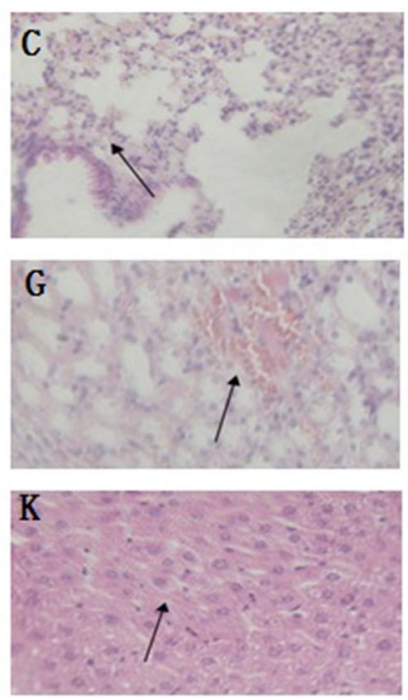
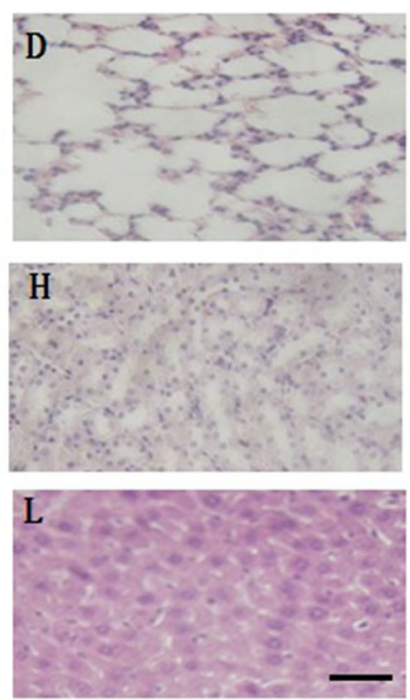

Fig. 2 Histopathological changes in the lungs (A-D), kidney (E-H) and liver (I-L) of mice infected by PCV2 (HE). Mice of group I (PBS) showed alveolar walls were thick and inflammatory cells were in the lung bronchia (a). Mice of group II (pVAX1) showed interstitial pneumonia, and congestion was observed in alveolar interlobular interval and infiltration with inflammatory cells (b). A few of inflammatory cells were observed in alveoli of group III (pVAX1-ORF2) (c). Wider congestion in the glomeruli was observed in group I-III, and degenerative necrosis in kidney tubules were observed in group I and II (e, f). The typical or slight vacuoles granular degeneration was observed in hepatocyte of group I or III,

respectively (i, $\mathbf{k})$. The hepatocyte of group II showed slight atrophy (j). No obvious unusual changes were observed in lungs, liver and kidney of group IV (d, h, I). The scale bar is $100 \mathrm{~mm}$

Fig. 3). The results showed that PCV2 were not detected in the position of injection which is neck muscles. Atthe first week after injection, while the PCV2 contents of groups III and IV were less than groups I and II $(p<$ 0.05). PCV2 were not detected in the tissues and blood of group IV at 3 weeks after injection, while the liver, spleen, kidney and blood have a few PCV2, which explained the virus was not eliminated completely. In addition, the amount of PCV2 in spleen was the highest in all the tissues and blood (Fig. 2).

Table 3 The testing result of PCV2 in the organs of mice

\begin{tabular}{|c|c|c|c|c|c|c|c|c|}
\hline days & Groups & heart & liver & spleen & lung & renal & muscle & blood \\
\hline \multirow[t]{4}{*}{$7 d$} & I & + & + & + & + & + & + & + \\
\hline & $\|$ & + & + & + & + & + & + & + \\
\hline & III & + & + & + & - & + & + & + \\
\hline & IV & + & + & + & + & + & - & + \\
\hline \multirow[t]{4}{*}{$14 d$} & 1 & + & + & + & + & + & + & + \\
\hline & $\|$ & + & + & + & + & + & + & + \\
\hline & III & + & + & + & - & + & - & + \\
\hline & IV & + & - & + & - & + & - & + \\
\hline \multirow[t]{4}{*}{$21 d$} & I & + & + & + & + & + & + & + \\
\hline & $\|$ & + & + & + & + & + & + & + \\
\hline & III & - & + & + & - & + & - & + \\
\hline & IV & - & - & - & - & - & - & - \\
\hline
\end{tabular}

\section{Discussions}

PCV2, the primary causative agent of PMWS, PRDC, mainly infected the weaned piglets (Allan et al., 1998), resulting in substantial economic losses to the pig industry. At present, there were not good drugs to treat with the diseases caused by PCV2. Thus, vaccine immunization has become a fundamental means and measures to prevent PCV2.

Nucleic acid vaccine is one of the hot spot of PCV2 vaccine researches. DNA vaccines may be capable of inducing immunity regardless of maternally derived antibodies $[14,15]$ and they have induced protective cellular and humoral immunity in preclinical models of infectious diseases. PCV2 Nucleic acid vaccine was first reported by Kamstrup [16], they developed and investigated the potential of DNA vaccination approach to against PCV2. Mice were vaccinated three times by gene gun and all mice responded serologically by raising antibodies against PCV2. They found that vaccination based on DNA might offer opportunities for vaccination of piglets against PCV2.

However, DNA vaccine applications are limited due to the problems related to delivery, species of the immunized animals and degradation of plasmid DNA. To compensate for these limitations, numerous studies have explored methods to improve immune responses induced by DNA immunization by optimizing plasmid design, vaccine delivery systems and adjuvants [17]. Adjuvants are of particular interest 


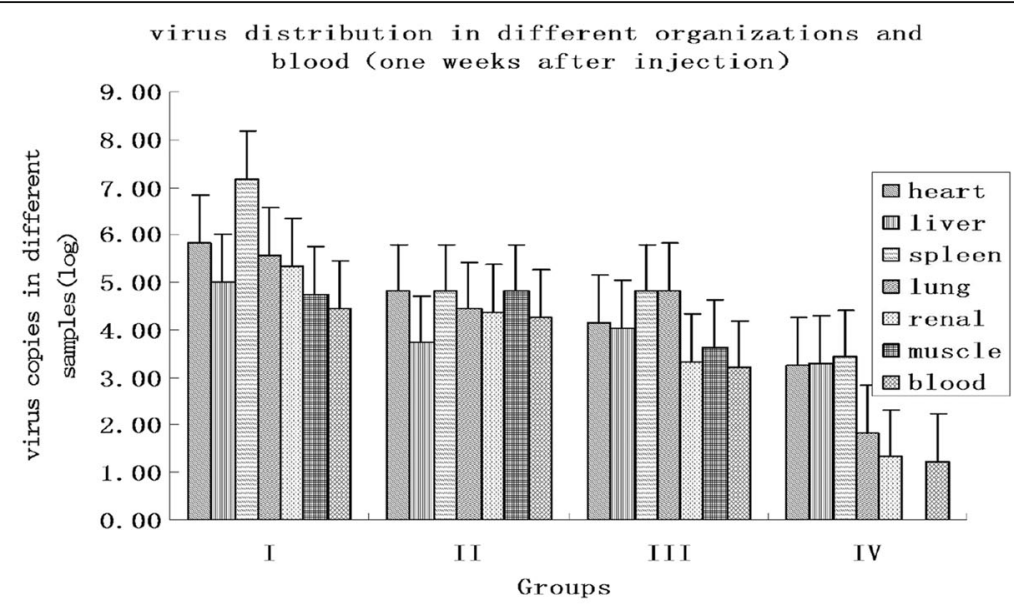

virus distribution in different organizations and blood (two weeks after injection)

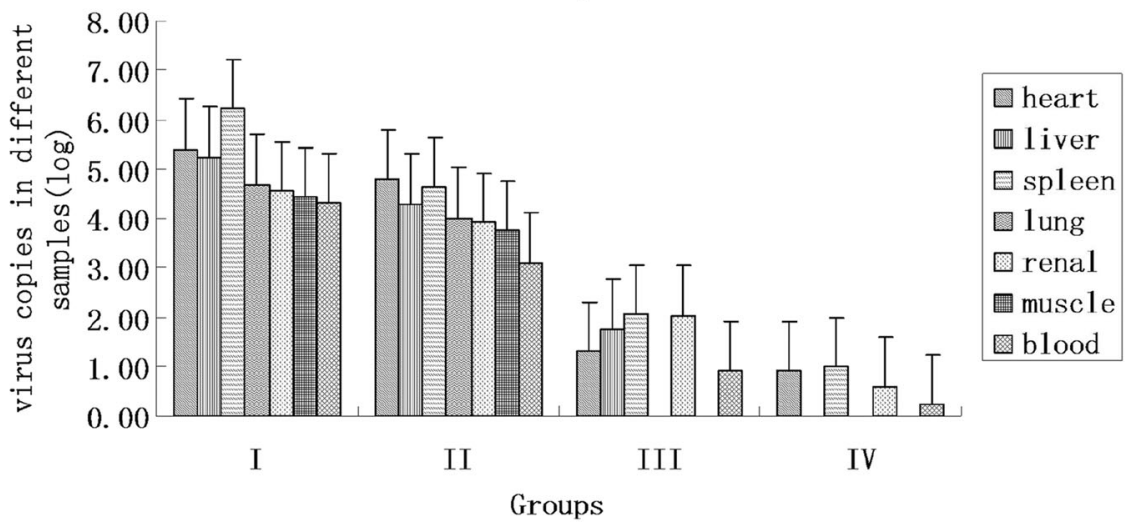

virus distribution in different organizations and blood (three weeks after injection)

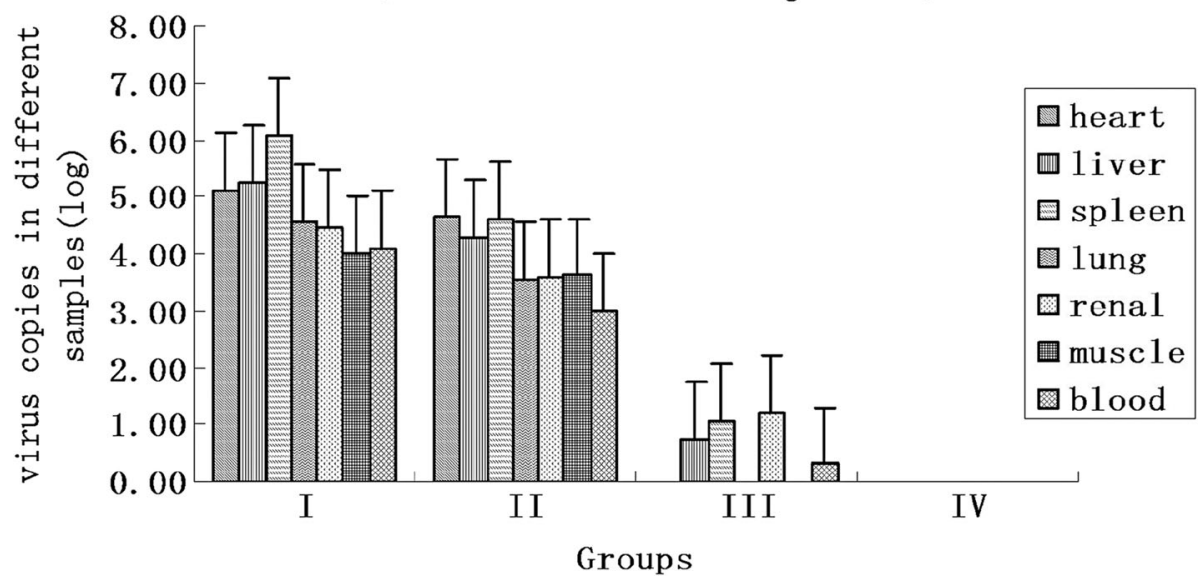

Fig. 3 The distribution of virus in different organizations of different periods

because they may enhance DNA delivery and increase the magnitude and duration of plasmid DNA expression [18]. Guo (2015) reported the enhancement of the immunogenicity of porcine circovirus type 2 DNA vaccines by using a recombinant plasmid coexpressing capsid protein and porcine interleukin-6 in mice. Dong [19] found that the mice co-inoculated with pVAX-PCV2-ORF2 plus pVAX-pIL-15 have higher humoral and cellular immune responses than the others. In addition, DNA plasmid bearing PCV2 ORF2 gene has a protective effect against challenge with PCV2 in mice which could be promoted with 
the utilization of pIL-15.Fu [20] evaluated three adjuvants Ubiquitin (ub), the peptide binding truncated C-terminal portion of heat shock protein 70 (hsp70c) and interleukin-2 (IL-2) in PCV2 DNA vaccine, they found that $\mathrm{ub}$ is a superior adjuvant for PCV2 DNA vaccination than the hsp70c and IL-2 molecules. Chen [21] evaluated two recombinant plasmids containing the ORF2 gene of porcine circovirus type 2 (PCV2) with or without porcine interleukin-18 (IL-18) and found that the plasmid pBudCE4.1-ORF2/IL18 may be an effective approach for increasing the immunogenicity of PCV2 DNA vaccine.

Our previous research demonstrated that CpG motifs as an adjuvant could boost the humoral and cellular immunity of pigs to against PCV2, especially in terms of cellular immunity [10]. This study evaluated the adjuvant of CpG motifs to PCV2 DNA vaccine and mainly detected the serum antibody levels in mice by ELISA. The results showed that the antibody levels of immune groups were increased, especially the nucleic acid vaccine containing $18 \mathrm{CpG}$, kept at a higher level throughout the immunization and decreased slowly, after challenge, it increased rapidly and could maintain a longer time.

The result of quantitative real-time PCR showed that PCV2 was replicated in the tissues of mice, while it was eliminated gradually in immune groups. Moreover, the content of PVC2 in spleen of all the tissues was the highest. The result of autopsy declared obvious lesions were appeared in group I and II, and minimal lesion was appeared in group III. No obvious unusual changes were observed in group IV.

\section{Conclusions}

In conclusion, the nucleic acid vaccine containing 18 CpG can build up resistibility immunity and reduce immune organ damage on mice. which has a wide prospect for preventing and controlling PCV2 infection.

\section{Acknowledgements}

The study was partly supported by Shandong Province Modern Agricultural Industry Technology System (SDAIT-08-07), Shandong Province Science and Technology Development Plan (2014GNC111011), Shandong Province agricultural applications of major innovation projects, Young Talents Training Program of Shandong Academy of Agricultural Sciences, Taishan Scholars Project, the Youth Scientific Research Foundation of Shandong Academy of Agricultural Sciences (2014QNM40,2016YQN53).

\section{Authors' contributions}

$J L, J Y, S J X, J L S, S N X, X Y W, F F, Z P, L L Z, S X Z, X Y Y, X Y C, W B S, K H C, Y J D$ and JQW carried out the experiments and wrote the manuscript. JBW conceived the studies and participated in experimental design and coordination. All authors read and approved the final manuscript.

\section{Competing interests}

The authors declare that they have no competing interests.

\section{Author details}

Division of Swine Diseases, Shandong Provincial Key Laboratory of Animal Disease Control \& Breeding, Institute of Animal Science and Veterinary Medicine Shandong Academy of Agricultural Sciences, Jinan 250100, China. ${ }^{2}$ Division of Swine Infectious Diseases, State Key Laboratory of Veterinary Biotechnology, Harbin Veterinary Research Institute, Chinese Academy of Agricultural Sciences, Harbin 150001, China.

Received: 3 June 2016 Accepted: 9 August 2016

Published online: 14 November 2016

\section{References}

1. Tischer I, Gelderblom H, Vettermann W, Koch M. A very small porcine virus with circular single-stranded DNA. Nature. 1982;295:64-6.

2. Allan GM, McNeilly F, Meehan BM, Kennedy S, Mackie DP, Ellis JA, Clark EG, Espuna E, Saubi N, Riera P, Bøtner A, Charreyre CE. Isolation and characterisation of circoviruses from pigs with wasting syndromes in Spain, Denmark and Northern Ireland. Vet Microbio. 1999;66:115-23.

3. Guo XQ, Wang LQ, Qiao H, Yang XW, Yang MF, Chen HY. Enhancement of the immunogenicity of a porcine circovirus type 2 DNA vaccine by a recombinant plasmid coexpressing capsid protein and porcine interleukin-6 in mice. Microbiol Immunol. 2015;59:174-80.

4. Fu F, Li XS, Lang YK, Yang YJ, Tong GZ, Li GX, Zhou YJ, Li X. Co-expression of Ubiquitin gene and capsid protein gene enhances the potency of DNA immunization of PCV2 in mice. Vriol J. 2011;8:1-9.

5. Zhu S, Zhang C, Wang J, Wei L, Quan R, Yang J, Yan X, Li Z, She R, Hu F, Liu J. Immunity Elicited by an Experimental Vaccine Based on Recombinant Flagellin-Porcine Circovirus Type 2 Cap Fusion Protein in Piglets. PLoS One. 2016;11:e0147432.

6. Sylla S, Cong YL, Sun YX, Yang GL, Ding XM, Yang ZQ, Zhou YL, Yang MN, Wang CF, Ding Z. Protective immunity conferred by porcine circovirus 2 ORF2-based DNA vaccine in mice. Microbiol Immunol. 2014;58:398-408.

7. Zhang H, Qian P, Peng B, Shi L, Chen HC, Li XM. A novel subunit vaccine co-expressing GM-CSF and PCV2b Cap protein enhances protective immunity against porcine circovirus type 2 in piglets. Vaccine. 2015;33: 2449-56.

8. Gomis S, Babiuk L, Godson DL, Allan B, Thrush T, Townsend H, Willson P, Waters E, Hecker R, Potter A. Protection of chickens against Escherichia coli infections by DNA containing CpG motifs. Infect Immun. 2003;71:857-63.

9. Mutwiri GK, Nichani AK, Babiuk S, Babiuk LA. Strategies for enhancing the immunostimulatory effects of $\mathrm{CpG}$ oligodeoxynucleotides. I Control Release. 2004;97:1-17.

10. Li J, Shi JL, Wu XY, Fu F, Yu J, Yuan XY, Peng Z, Cong XY, Xu SJ, Sun WB. Improvement of the immunogenicity of Porcine Circovirus Type 2 DNA vaccine by recombinant ORF2 gene and CpG motifs. Viral Immunol. 2015; 28:290-6.

11. Li J, Yuan XY, Zhang CF, Miao LF, Wu JQ, Shi JL, Xu SJ, Cui SJ, Wang JB, Ai HB. A mouse model to study infection against porcine circovirus type 2 : viral distribution and lesions in mouse. Virol J. 2010;7:1-6.

12. Kiupel M, Stevenson GW, Choi J, Latimer KS, Kanitz CL, Mittal SK. Viral replication and lesions in BALB/C mice experimentally inoculated with porcine circovirus isolated from a pig with postweaning multisystemic wasting disease. Vet Pathol. 2001;38:74-82.

13. Li J, Shi JL, Wu XY, Cong XY, Xu SJ, Yuan XY, Wu JQ, Sun WB, Du YJ, Peng Z, Wang JB, Huang BH. Differentiation of PCV1 and PCV2 by a multiplex realtime PCR assay. Vet Rec. 2013;173:346-7.

14. Fischer L, Barzu S, Andreoni C, Buisson N, Brun A, Audonnet JC. DNA vaccination of neonate piglets in the face of maternal immunity induces humoral memory and protection against a virulent pseudorabies virus challenge. Vaccine. 2003;21:1732-41.

15. Weeratna RD, Brazolot Millan CL, McCluskie MJ, Siegrist CA, Davis HL. Priming of immune responses to hepatitis B surface antigen in young mice immunized in the presence of maternally derived antibodies. FEMS Immunol Med Microbiol. 2001;30:241-7.

16. Kamstrup S, Barfoed AM, Frimann TH, Ladekjær-Mikkelsen AS, Bøtner A. Immunisation against PCV2 structural protein by DNA vaccination of mice. Vaccine. 2004;22:1358-61.

17. Lu S, Wang S, Grimes-Serrano JM. Current progress of DNA vaccine studies in humans. Expert Rev Vaccines. 2008;7:175-91.

18. Greenland JR, Letvin NL. Chemical adjuvants for plasmid DNA vaccines. Vaccine. 2007;25:3731-41. 
19. Dong B, Feng J, Lin H, Li LXSD, Tu D, Zhu W, Yang Q, Ren X. Immune responses of mice immunized by DNA plasmids encoding PCV2 ORF 2 gene, porcine IL-15 or the both. Vaccine. 2013;31:5736-44.

20. Fu F, Lang Y, Li X, Chai Z, Tong G, Liu S, Tian H, Li H, Wang W, Chen X, Li X. Evaluation of the enhancing ability of three adjuvants for DNA vaccination using the porcine circovirus type 2 ORF2 (capsid) gene in mice. Virus Res. 2013;171:247-51.

21. Chen GL, Fu PF, Wang LQ, Li XS, Chen HY. Immune responses of piglets immunized by a recombinant plasmid containing porcine circovirus type 2 and porcine interleukin-18 genes. Viral Immunol. 2014;27:521-8.

Submit your next manuscript to BioMed Central and we will help you at every step:

- We accept pre-submission inquiries

- Our selector tool helps you to find the most relevant journal

- We provide round the clock customer support

- Convenient online submission

- Thorough peer review

- Inclusion in PubMed and all major indexing services

- Maximum visibility for your research

Submit your manuscript at www.biomedcentral.com/submit
Biomed Central 